\title{
THE REFLECTIONS OF PRE-SERVICE EFL TEACHERS ON OVERCOMING FOREIGN LANGUAGE TEACHING ANXIETY (FLTA) DURING TEACHING PRACTICUM
}

\author{
Dilek Tüfekçi Can \\ Balıkesir University, Balıkesir, Turkey \\ E-Mail: tufekci@balikesir.edu.tr
}

\begin{abstract}
Whereas research on English as a Foreign Language Learning (EFLL) anxiety has been the focus of many researchers, English as a Foreign Language Teaching (EFLT) anxiety as a newly pop-up concept has gained lesser attention than EFLL. Moreover, the research on EFLL commonly focuses on the anxiety provoking factors. Yet again, there has been very limited research on how to overcome anxiety-provoking factors on both research areas. Accordingly, as this study was two of the three segments of a university-based project and the subject of anxiety-provoking factors was the issue of another study, the purpose of this study was firstly to explore how to overcome anxiety-provoking factors among pre-service EFL teachers while teaching English to young language learners at a real classroom setting as a part of teaching practicum. Secondly, this study also attempted to make a holistic classification rather than an atomistic one as it classified the findings of overcoming anxiety provoking factors into subtitles such as cognitive, affective, sociocultural resolutions and some other official resolutions. In the study, 25 EFL pre-service teachers at Balikesir University were the sample group. The qualitative data was collected through background questionnaires, interviews and reflections. The study concluded that pre-service EFL teachers revealed their reflections on how to overcome anxiety-provoking factors as they experienced Foreign Language Teaching Anxiety (FLTA) whilst practicing teaching English to young language learners during teaching practicum courses. Some practical recommendations were given at the end of the study.
\end{abstract}

Key words: English as a foreign language, teaching anxiety, teaching practicum, anxietyprovoking factors, pre-service teachers

\section{INTRODUCTION}

In the literature review, whereas many researches have been carried out on Foreign Language Learning Anxiety (FLLA), the research on Foreign Language Teaching Anxiety (FLTA) has fallen behind significantly. Even though there has been a growing interest in FLTA recently, particularly in English as a Foreign Language, the research on FLLA are more than those on FLTA. In his research, Tum (2012) made a statement about the extent of the research on anxiety in the literature and stated that the research carried out on learning anxiety outweighed the research on FLTA in number. Accordingly, it would not be wrong to state that the research carried out on the factors of FLLA also outweighs in number the research carried out on FLTA. Moreover, the research on the resolutions of FLTA are rather limited in the literature than those on the factors of FLTA. Thus, this study was conducted in order to fill the gap in the literature as the purpose of

Submitted July $28^{\text {th }}, 2018$, accepted for publication October $29^{\text {th }}, 2018$ 
this study is mainly related with the ways of overcoming anxiety-provoking factors in foreign language teaching.

Whereas the sources of FLTA were one of the three segments of a research project entitled A Qualitative Research: On Foreign Language Teaching Anxiety among Preservice Teachers of English as a Foreign Language (EFL) with the ID 2017/175 and this study was two of the three segments of aforementioned project, it must be noted that the sources of FLTA is not a subject of this research. This study rather focuses on the preservice EFL teachers' reflections on how to overcome anxiety-provoking factors while they are practicing teaching English to young language learners during teaching practicum.

\section{LITERATURE REVIEW}

Anxiety as an affective variable has been recognized as a significant research area both in second language acquisition and foreign language learning because of the negative effect it may have on students' performances. In other words, feelings of anxiety, apprehension and nervousness are common indicators or signs of a negative or detrimental effect on communication in the target language. The studies conducted on anxiety in the literature are commonly on foreign language learning anxiety. For instance, Horwitz, Horwitz and Cope (1986) were among the first researchers who introduced the concept of FLLA and who also created Foreign Language Classroom Anxiety Scale (FLCAS). In their study, they concluded that FLLA has a strong effect on language learning process and suggested that more effort should be spent to develop methods to reduce anxiety in order to improve language acquisition. Likewise, Dörnyei (2005) also stated that anxiety was one of the most prevalent factors which inhibited the learning process. Whereas the studies were generally conducted on FLLA at the very beginning, the studies on FLTA came into recognition by the researchers after a while as well. For instance, Horwitz (1996) was again the first researchers to attach importance on FLTA as he indicated that FLTA may have a negative effect on instruction. Merç (2010) also revealed that anxious teachers might be more liable to avoid certain teaching styles and activities. In another study (Merç, 2015), the relationship between FLTA and language teaching self-efficacy beliefs of pre-service EFL teachers was examined through both qualitative and quantitative data. The result showed that pre-service EFL teachers experienced low level of FLTA; however, it also revealed that their relationship with their mentors was found to be the most anxiety-provoking factors. Another study (Kunt \& Tüm, 2010) researched the feelings of pre-service EFL teachers in North Cyprus by administering the Turkish version of Horwitz's (1986) FLCAC. The result revealed that non-native student teachers experienced foreign language anxiety at various levels that might negatively affect themselves and their teaching performance. Another study (Aslrasouli \& Vahid, 2014) attempted to investigate teacher anxiety among practicing EFL teachers in the Iranian context. The result revealed that about $57.65 \%$ of teachers had the feelings of anxiety in areas such as interpersonal relations, employment structure, language proficiency and knowledge, facilities and resources.

In the literature review, the research conducted on reducing or overcoming FLTA was rather limited when compared to FLLA. Speaking specifically, some studies (Kim, 2009; Pichette, 2009; Hurd \& Xiao, 2010) in FLLA examined the anxiety levels and profiles of 
the foreign language learners in different language learning contexts whereas some (Suwantarathip \& Wichadee, 2010) others explored the effectiveness of some of the approach such as cooperative learning in reducing foreign language anxiety. Similarly, in the literature, whereas some of the studies on FLLA examined the relationship between EFL reading and anxiety (Güvendir, 2014; Zoghi, Alivandivafa, 2014; Matsuda, Gobel, 2004), some of the others surveyed the relationship between language anxiety and course achievement (Backman, 1976; Tucker, 1976; Young, 1986; Marcos-Llinás, Garau, 2009). Moreover, there have been a number of studies on the different aspects of anxiety as well. For instance, Chen \& Chang (2004) conducted their studies on EFL anxiety and learning difficulties while Lim's (2009) study, which indicated that the students' country of origin affected the degree of language anxiety, examined the relationship between culture and anxiety.

In a similar vein, Trang, Baldauf, and Moni (2013) examined the extent to which foreign language students and teachers at a Vietnam university were aware of the existence of FLA and their attitudes towards it. The findings indicated that nearly two thirds of the students suffered from FLA to some degree; however, it was also found that the teachers did not pay adequate attention to it. Furthermore, Trang and Moni (2015) conducted their research on how to manage FLA by considering the EFL students' and teachers' perspectives and experiences. In the research, a dual-task approach was used in order to cope with FLA by implementing some specific strategies for students and teachers. The results revealed that it should not be expected a one size fits all model for FLA management. Thus, the result also revealed that it was significant to focus on working with FLA instead of only focusing on reducing it.

In their studies, Dewaele, Petrides and Furnham (2008) examined the communicative language learning and foreign language anxiety. The results indicated that the knowledge of more languages, a higher frequency of use, a stronger socialization in a language, a larger network of interlocutors, and a higher level of self-perceived proficiency in a language were also linked to lower levels of communicative anxiety and FLA. The results of another study (Wu, 2010) showed that whereas most of the participants expressed a favorable attitude toward the Communicative Language Teaching (CLT) approach, they also revealed their high level of anxiety in the language classroom. In this study, it was also stated that teaching students how to learn more effectively and efficiently was under the responsibility of their instructors as Language Learning Strategies (LLS) were regarded as the procedures that learners could use to facilitate learning.

The result of another study (Bosmans \& Hurd, 2016) indicated that there was a significant correlation between good pronunciation skills and low levels of FLA, particularly when learning occurred in a distance setting. In another study (Anandari, 2015), Indonesian EFL students' anxiety in speech production was researched in terms of speech-production-related foreign-language anxiety. The result showed that there were three causes of foreign language anxiety: fear, shyness, and discomfort. The results also demonstrated that self-reflections helped the students cope with FLA as they were helpful for students in identifying their strengths and weaknesses, conducting problem solving, and increasing confidence. Another study (Szyszka, 2011) attempted to investigate the link between foreign language anxiety and the self-perceived levels of pronunciation of EFL students. The result indicated that a negative correlation was found between the level of language anxiety and self-perceived English pronunciation competence. In other words, the results showed that more apprehensive teacher trainees perceived their 
pronunciation as poor, whereas those with lower levels of anxiety declared higher pronunciation competence.

The purpose of another study (GhorbanDordinejad \& Nasab, 2013) was to find out the relationship between perfectionism and English language achievement mediated by foreign language classroom anxiety. The results revealed a positive association between perfectionism and foreign language anxiety. However, the results also revealed that maladaptive perfectionists were found to be more anxious than adaptive and nonperfectionist. In a Turkish context study (Tum, 2015), the result indicated that anxious pre-service teachers experience significant levels of language anxiety to a degree that might cause them to avoid using the target language and language-intensive teaching practices in their classrooms.

The studies conducted on FLA were typically and habitually based on the sources of FLLA or, on FLTA with a considerable fewer number. However, few studies emerged predominantly on the resolutions or on how to alleviate FLTA in the literature. For instance, in his study, Tanveer (2007) enumerated the less anxiety provoking factors as friendly classroom environments, drama-like activities, avoidance of idealized forms of pronunciation and homogenous classes. Furthermore, in order to reduce anxiety in classrooms, cooperative learning has been suggested in some of the studies conducted by some of the researchers (Johnson, Johnson \& Holubec, 1990; Slavin, 1991; Oxford, 1997; Bailey, Daley \& Onwuegbuzie,1999; Duxbury \& Tsai, 2010; Nejad \& Keshavarzi, 2015). Moreover, some of the other studies proposed some strategies on coping with the anxiety of the students. For instance, the study of Kondo and Ying-Ling (2004) offered a typology of strategy and classified the ways to reduce anxiety under five headings, such as preparation, relaxation, positive thinking, peer seeking and resignation. In another study (Saglamel \& Kayaoglu, 2013) in a Turkish context, the language anxiety level of Turkish students was explored in terms of the role of creative drama played in reducing language anxiety in speaking classes. The results revealed that anxiety levels of students taking active parts in the creative drama program was found to be significantly and statistically in decrease.

At last, the main purpose of this study was to show some significant factors on FLTA. As the results of this research, which were collected from the reflections of pre-service EFL teachers, clearly indicated how to overcome anxiety-provoking factors in terms of a new classification such as cognitive, affective and socio-cultural resolutions, as well as some other official resolutions, this study would bring a new perspective on overcoming anxiety-provoking factors. Moreover, since the researcher of this paper has been working at Foreign Languages Teaching Department, particularly at English Language Teaching Department for more than 15 years, she has witnessed the pre-service EFL teachers' anxiety on teaching rather than learning while they are participating at Teaching Practicum courses. Accordingly, this study aimed to explore how pre-service EFL teachers have overcome anxiety-provoking factors while teaching English to young language learners at a real class setting as a part of teaching practicum. Thus, based on the existing literature on pre-service teachers' anxiety and on the previous research the researcher has already conducted on the anxiety-provoking factors, only the following research question was formed in this research:

What should be done to overcome the anxiety-provoking factors experienced by nonnative pre-service EFL teachers while teaching English to young language learners during teaching practicum? 


\section{METHODOLOGY}

\subsection{Research Design}

The present study was structured according to the qualitative research design by using multiple data collection methods, including a background questionnaire, interviews and reflections. As stated by Rallis and Rossman (2003), as qualitative research, this study is based on a kind of “... inquiry [which] proceeds through a complex, nonlinear process of induction, deduction, reflection, inspiration, and just plain [...] thinking" $(2003,11)$. Since it employs uncovering textual data and examining it using interpretive analysis, it "... focuses on understanding the particular and the distinctive, [and it] does not necessarily seek or claim to generalize findings to other context" (Croker, 2009, 9). Moreover, this study included data collection procedures generally result in open-ended and non-numerical data (Dörnyei, 2007).

\subsection{Participants}

In the study, there were 25 pre-service EFL teachers as participants, namely 7 males and 18 females, each of whom given a number such as S1, S2, S3 and so on. The participants in this study were among the $4^{\text {th }}$ year students at the ELT department. The mean age was 23.6, in the range of 21 to 41 . Of the participants, 28\% (7) were males, whereas $72 \%$ (18) were females who were taking Teaching Practicum course as an obligatory course in 2016-2017. The research lasted 14 weeks in English Language Teaching Department, at Balikesir University in Turkey.

\subsection{Data Collection Instruments}

This qualitative study used firstly a background questionnaire, secondly interviews and thirdly reflections of the participants for the data collection instruments. The participants were given a background questionnaire before the research, which yielded demographic information about them. In face to face interviews, the participants were asked some interrelated questions as to participants' awareness of their level of teaching anxiety, how to overcome anxiety-provoking factors, what their suggestions were for tackling the problem, what could the best resolutions for overcoming teaching anxiety be. However, the questions centered on examining the pre-service EFL teachers' opinions developed along the interaction with the process of interviews which were held each week. Secondly, the written reflections of the pre-service EFL teachers as self-report methods were also used in the research as the data collection instrument. In the study, a combination of questionnaire, interviews and written reflections were used in order to provide more security and validity in this study.

\subsection{Procedure}

In order to conduct this research, a research proposal along with a document which gives specific details about the whole procedure in relation to its purpose, methodology, data collection and data analysis, was given to justify the need to study the aforementioned research question to the administrators of Necatibey Faculty of Education, Balikesir University, Turkey. Soon after the proposal was examined and accepted, the researcher informed the participants about the procedure. Since this study 
involved three different data collection instruments, particularly the participants who were hesitant about whether their rights would be protected or not in each process were reassured about the confidentiality of their personality as participants. And then the participants who willingly participated in the first phase of the research and the reassured ones in the second phase of the research were kindly informed that they would also be notified about the results of the research. In this study, firstly instruction, secondly practice, thirdly data collection and lastly data analysis were enumerated below to show the phases of the research one by one.

\subsubsection{Instruction}

In the instruction part, no sooner than the researcher introduced the whole procedure on the research, particularly on the purpose, methodology, data collection and data analysis parts, the consents of the participants were taken individually. In other words, the researcher attempted to make each participant feel safe about the research and she made clear explanations on the issue and described the process in detail. When the participants gave their both oral and written consents on agreeing to be a part of the research, the researcher began her research.

\subsubsection{Practice}

In the practice part, shortly after some prerequisite information was given about the research and a background questionnaire was employed in the first week, the participants were grouped in five. Accordingly, each of the five groups were interviewed each week either individually or together. In those face to face meetings, the researcher took some notes when the participants made some important statements on the ways of overcoming FLTA. Each interview was dated and documented for 14 weeks, each of which were conducted systematically and periodically. The main reason of such a registration was to define their longitudinal perspective on overcoming FLTA. The researcher was also open to any kind of data share of the participants through e-mails and the use of all smart phone applications such as WhatsApp, Twitter, Facebook message and Instagram. Thus, the participants felt free to share any experience they had at the teaching practicum courses and were able to reach the researcher any time they wanted. The participants also handed their written reflections in fortnight intervals, which accounts for a seven-week written reflection in total within a 14 week of study.

\subsubsection{Data Collection}

In this phase, firstly a background questionnaire, which included information on the participants age and gender, were used to collect data. And secondly, interviews were used as the data collection. The open-ended questions were instantaneously raised in connection with the study. For instance, what the pre-service EFL teachers did when they encountered a specific or a general problem both personally and academically, how they dealt with the anxiety-provoking factors either cognitively, affectively or socio-culturally, what they thought of the ways of overcoming anxiety-provoking factors, how they attempted at succeeding in overcoming anxiety-provoking factors, and how they overcome their anxiety when they felt they were under stress or unsafe. Last of all, the participants' accounts of written reflections were collected at the end of each fortnight. 


\subsubsection{Practice}

In the practice phase, the data from each source were analyzed independently and the statements, judgements and references on how to overcome anxiety-provoking factors among pre-service EFL teachers were coded under certain themes. Since all of the three aforementioned data collection instruments had a function which served our aim, namely they all helped to collect qualitative data, the participants' background questionnaires were examined, and a general information was gained about their ages and gender. The data from the participants' interviews were firstly decoded and then they were coded under cognitive, affective and socio-cultural resolutions. As the previous research on this project was on the anxiety-provoking factors in FLT and the results of which were coded identical such as cognitive, affective and socio-cultural factors, this study also outlined the FLTA with the same titles such as cognitive, affective and socio-cultural resolutions. In other words, each of the participants' statements were coded under such titles as shown in the concept map in the following part. Then the use of third data collection instrument, namely written reflections of the participants contributed to the research as the written reflections clearly elucidated the interviews of the participants the researcher carried out both individually and in groups. Then a concept map was prepared by transferring the data collected in relation to the classification and codification of the statements, judgements and references from the participants. When a comparative analysis was made among the statements and numbers in concept maps, the data on how to overcome anxiety-provoking factors among pre-service teachers were found to be analogous. In short, the conjointly found data were presented with the numbers and the frequencies below.

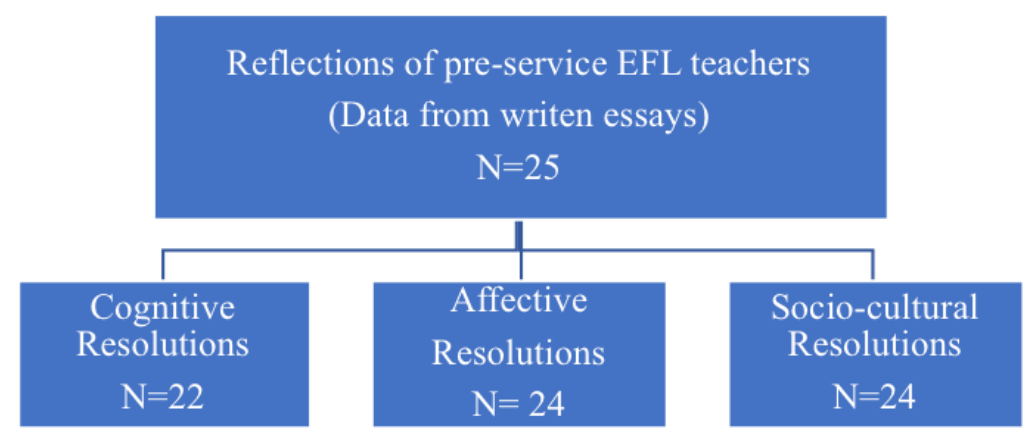

Model 1 Concept Map on the Reflections of pre-service EFL teachers

\section{FINDINGS}

Before dealing with the reflections of pre-service EFL teachers on how to overcome anxiety-provoking factors, it is of great significance to briefly mention the results of previous research which was correlated with this research carried out by the same researcher. As this study was one of the parts of the previous research, and it was conducted to find out the anxiety-provoking factors among pre-service EFL teachers, some brief information needs to be given about the results in order to elucidate the results 
of this research. The results of the previous research (Tufekçi Can, 2018) were classified into three such as cognitive, affective and socio-cultural factors in FLTA.

As for cognitive factors, the results showed that the pre-service EFL teachers experienced FLTA when they were aware that they were incompetent in teaching the theme appropriately; they were academically evaluated by practice teachers; they made mistakes particularly on grammar and vocabulary; they used their practice time recklessly and unproductively; they used the unsuitable materials; they had difficulty in practicing at a diverse class; they could not use the interactive board; they were unable to see importance of the teaching practicum as they had to study for a general exam named KPSS, which is a requisite for the pre-service EFL teachers to be appointed as teachers at the governmental schools in Turkey; they were incapable of responding to the students' questions; they were incompetent in following the content of course book (Tüfekçi Can, 2018, 588).

As for affective factors, the results indicated that the pre-service EFL teachers experienced FLTA when they overthought that they lost class management; they would be unconstructively criticized by the practice teachers; they were mistreated or neglected by the practice teachers who displayed no signs of tolerance; they were under constant surveillance by the practice teachers; they had trouble in accommodating themselves a distinctive identity as a teacher and in speaking in public; they had low self-confidence; they were not quite prepared for the class; they were aware of the reluctance of the practice teachers to teach the course; they recognized the lack of concession between the coterie teachers; they got the feeling that coterie teachers compete with each other (Tüfekçi Can, 2018, 589)

As for socio-cultural factors, the results suggested that the pre-service EFL teachers experienced FLTA when they realized that the students in the class misbehaved towards them; they had to manage overcrowded classrooms; they were not satisfied with the physical conditions of the schools; they could not handle with extreme noise; they could not differentiate the students as girls and boys; they had difficulty in organizing group/pair work; they had problems in terms of atmosphere, setting and transportation about the practice school; they had to be with all other teachers in the teachers' room (Tüfekçi Can, 2018, 589).

In conclusion, the results of the previous study (Tüfekçi Can, 2018) indicated that the pre-service EFL teachers experienced mainly three different types of FLTA. Similarly, the results of this study also revealed that the pre-service EFL teachers revealed some resolutions on how to overcome anxiety-provoking factors under the same classification such as cognitive, affective and socio-cultural resolutions.

In the following part, the pre-service EFL teachers' overcoming anxiety-provoking factors are presented in terms of cognitive resolutions. 
Table 1

\begin{tabular}{|lrr|}
\hline Cognitive Resolutions & f & $\%$ \\
\hline Pre-service EFL teachers should be... & 8 & 15.70 \\
\hline 1. informed on the process of teaching practice. & 7 & 13.73 \\
2. informed about the curriculum before. & 7 & 13.73 \\
3. informed about interactive boards before. & 6 & 11.76 \\
4. taught active language learning techniques. & 5 & 9.80 \\
5. mentally trained on soothing their anxiety. & 5 & 9.80 \\
6. trained on how to teach in different levels. & 3 & 5.88 \\
7. helped cognitively by their supervisors. & 3 & 5.88 \\
8. productively involved in classroom discourse. & 3 & 5.88 \\
9. given complete responsibility in teaching. & 2 & 3.92 \\
10. knowledgeable on practicing different activities & 2 & 3.92 \\
11. well-prepared for the class before. & 51 & 100.00 \\
\hline Total
\end{tabular}

The following three excerpts were the cognitive resolutions of the pre-service EFL teachers. The S1 was an aged and experienced pre-service EFL teacher, who had graduated from a different program and had a teaching experience abroad with the students at least 5 years. S/he suggested the following for beginner teachers to reduce their anxiety level.

S1: They should always be prepared for the class in terms of teaching material. They should mentally be well-prepared for the lesson. Teachers should be able to concentrate on their lessons and forget everything except their students. They should have a lesson plan. All the stages of the lesson should be planned carefully. A plan should be flexible, and if it requires any regulation, the teacher should replace it easily. Teachers should prepare authentic materials and activities. Teachers should be aware of their students' needs and interest.

Another phenomenon observed in the excerpts was that the participants focused on active language learning techniques and practice as well as language skills and communicative skills.

S9: I could cope with my anxiety only if I had been informed on the process of teaching practicum properly. Because if I were well-prepared to the subject I am dealing with, I can control myself. Otherwise, I am unable to control my anxiety. In addition to this, I should have some knowledge on active teaching techniques to improve my social relationship with the class. The stronger the relationship between teacher-student and student-student becomes, the better the interaction and communication between them happen.

S22: In order to overcome my anxiety-provoking factors, I can improve myself more in terms of my knowledge on English language teaching, I can change my attitude to students, I can make more practice on teaching language skills and communicative skills.

In the following part, the pre-service EFL teachers' overcoming anxiety-provoking factors are presented in terms of affective resolutions. 
Table 2

\begin{tabular}{|lrr|}
\hline \multicolumn{1}{|c|}{ Affective Resolutions } & f & \% \\
\hline \multicolumn{1}{|c|}{ Pre-service EFL teachers should... } & 16 & 18.40 \\
\hline 1. be motivated to feel themselves as real teachers. & 12 & 13.79 \\
2. be trained on class management practically. & 11 & 12.64 \\
3. have a friendly interaction with the practice teachers. & 10 & 11.49 \\
4. be on good terms with the faculty supervisors. & 8 & 9.20 \\
5. have a good rapport with the students in the class. & 7 & 8.04 \\
6. be made aware of the probable problems. & 7 & 8.04 \\
7. be able to use an effective classroom discourse. & 5 & 5.75 \\
8. should ignore their introvert personality. & 5 & 5.75 \\
9. increase their self-confidence. & 4 & 4.60 \\
10. observe the students' needs and interests. & 2 & 2.30 \\
11. change their patronizing attitudes to students. & 87 & 100.00 \\
\hline \multicolumn{1}{|c|}{ Total } & & \\
\hline
\end{tabular}

The following excerpt, namely S12, which included affective resolutions, clearly indicated the pre-service EFL teachers' great concern on the complete surveillance of the practice teachers which they assumed a kind of interruption or disruption on their communication with the students in class.

S12: The pre-service teachers should be given complete responsibility in the class. Under the close surveillance of practice teachers, the pre-service EFL teachers are unable to communicate with the students in a realistic manner. The communication under these circumstances becomes rather artificial. In order to overcome their anxiety, the preservice EFL teachers should feel freer in class settings.

S19: Establishing a close relationship between me and my practice teacher works a lot in reducing my anxiety. When the practice teacher is arrogant and overconfident, his reaction also affects me and triggers my anxiety. I cannot stop myself being anxious. The cooperation between my practice teacher and my teacher trainer is the most important aspect in overcoming my anxiety. If they have difficulty in communication, I am fearful of failing from the teaching practicum.

S16: Teaching itself is not a stress-free activity. Teaching does not require only knowledge, it requires other skills as well. For instance, how to manage class, how to communicate with students, how to communicate with other colleagues, these are completely new things for the beginners. Thus, anxiety may not be too bad at all. A certain amount of anxiety gets adrenaline flowing, which helps lift our performance and teach in a more dynamic way.

In the following part, the pre-service EFL teachers' overcoming anxiety-provoking factors are presented in terms of socio-cultural resolutions.

Table 3 Socio-cultural Resolutions on Overcoming Anxiety Provoking Factors 


\begin{tabular}{|lrr|}
\hline \multicolumn{1}{|c|}{ Socio-cultural Resolutions } & f & \% \\
\hline Pre-service EFL teachers should ... & 12 & 15.19 \\
\hline 1. be introduced as real teachers not as pre-service teachers. & 12 & 15.19 \\
2. be trained only by the experienced practice teachers. & 11 & 13.93 \\
3. practice in class without the existence of practice teachers. & 10 & 12.66 \\
4. be provided with constructive feedback on their progress. & 9 & 11.39 \\
5. be treated as one who needs guidance rather than servants. & 6 & 7.59 \\
6. share their anxiety-provoking experience with others. & 5 & 6.33 \\
7. be trained to improve their social/official relationships. & 5 & 6.33 \\
8. build up a good rapport among the students. & 4 & 5.06 \\
9. be trained to be able to speak before the public. & 3 & 3.80 \\
10. be trained on pair, group work and activities. & 2 & 2.53 \\
11. be introduced to the surroundings of the school setting. & 79 & 100.00 \\
\hline Total &
\end{tabular}

In the following excerpts, the participants shared their socio-cultural perspectives and resolutions to FLTA in class.

S7: I should be introduced as a real teacher, not pre-service EFL teacher. Because when the students in the class learn that I am a novice, they never respect me as a teacher. The presence of the practice teachers in the class creates an unpleasant situation both for the students and for the teacher.

S24: One of the best ways of overcoming my anxiety is to make the students participate in collaborative activities. While they are trying to do the instructions, I can take time and reflect on my anxiety. In my opinion, how I can make my own anxiety feel lesser and more manageable completely depends on how much I am prepared to teach in a real class setting. The more practice you do in class, the better results you get. The better results you get, the less anxious you become.

S10: The pre-service EFL teachers should never be considered slaves who are ready to provide any kind of services that the practice teachers ordered them to do. They should be regarded as the ones who are about to begin the profession of teaching and who need guidance. That's all.

In the last part, the pre-service EFL teachers' overcoming anxiety-provoking factors are presented in terms of some other official resolutions.

Table 4 Some Other Official Resolutions on Overcoming Anxiety Provoking Factors

\begin{tabular}{|l|r|r|}
\hline Some Other Official Resolutions & f & \% \\
\hline 1. The year of teaching practicum and KPSS should never coincide with each other. & 22 & 18.65 \\
2. Teaching practicum should be carried out at the $2^{\text {nd }}$ and $3^{\text {rd }}$ years. & 21 & 17.80 \\
3. A certain day should be arranged for teaching practicum. & 18 & 15.25 \\
4. Faculty's weekly course programs should be arranged in connection with teaching & 16 & 13.56 \\
practicum. & & \\
5. The pre-service EFL teachers should be given chance to be trained in every sphere of & 12 & 10.17 \\
education. & & \\
6. Teacher trainers should visit the practice schools at least 3 times. & 10 & 8.47 \\
7. Both practice teachers and teacher trainers should cooperate with each other. & 9 & 7.63 \\
8. The pre-service teachers should choose the practice school rather than the teacher & 6 & 5.08 \\
trainer. & & 3.39 \\
9. The pre-service EFL teachers should be awarded with a symbolic amount of money \\
paid by the government.
\end{tabular}


In the following excerpts, the participants suggested some other official resolutions in order to overcome FLTA.

S3: The practice teachers, teacher trainers and the pre-service teachers should be entitled to in-service education and training. Only under these circumstances can I assume that the teaching practicum can be given more priority in English language teaching departments. Moreover, the duration of teaching practice should be increased. The pre-service teachers should be trained at the same school in two terms.

S6: One of most anxiety-provoking factors is the practice teachers themselves. The practice teachers should be entitled to regular in-service education and training through a workshop as most of the practice teachers are inexperienced and they do not have any idea on how to carry out this course and on how to behave and train the pre-service EFL teachers. Experience does not mean that the pre-service teachers should have experience as they are aged, but it means something totally different.

S25: In addition to this, more time should be allowed to teaching practicum course. For instance, in a week one day can be arranged as a practice day for the teaching practicum courses. There should be no classes in this day in the weekly schedule of the pre-service EFL teachers. And once more, each pre-service EFL teachers should be given the responsibility of a class and at the end of the process, both the students' and the pre-service EFL teachers' improvement can be observed. In order to do this, the pre-service teachers should be given some information on the class beforehand by the practice teachers.

In sum, the findings indicated that the pre-service EFL teachers revealed cognitive, affective and socio-cultural resolutions in order to overcome FLTA in a real class setting. Among many others, the resolutions related with the official ones can be considered the utmost important ones, awaiting some governmental solutions as well as ministerial ones. For instance, the coincidence of KPSS with teaching practicum; the duration of the teaching practicum in terms of the class it was taken; the arrangement of a certain day for the teaching practicum; the arrangement of faculty's weekly program with teaching practicum's 6 hours of attendance; having the opportunity to be trained in every sphere of education such as primary, secondary and high schools and cooperation of practice teachers with teacher trainers are the solutions offered by the pre-service EFL teachers.

\section{DISCUSSION}

As indicated in the limited research, contrary to the research carried out on anxietyprovoking factors, the research carried out on how to overcome anxiety-provoking factors are rather limited particularly among pre-service EFL teachers. In the literature, in order to alleviate anxiety-provoking factors, the use of self-reflections (Anandari, 2015); the participation of creative drama programmes (Saglamel \& Kayaoglu, 2013); the cooperative learning (Johnson, Johnson, \& Holubec, 1990; Slavin, 1991; Oxford, 1997; Bailey, Daley \& Onwuegbuzie,1999; Suwantarathip, Wichadee, 2010; Duxbury \& Tsai, 2010; Nejad \& Keshavarzi, 2015) were suggested. However, in this study, the findings did not negate the results found in the previous studies as well in terms of their suggestions such as the use of self-reflections, participating drama programs and cooperative learning. Yet again, this study offers a new classification such as cognitive, affective and socio-cultural resolutions to alleviate anxiety-provoking factors.

Some practical recommendations can be noted. 
1. FLTA can be included in the curriculum by putting forward some concrete resolutions on overcoming anxiety-provoking factors.

2. The pre-service EFL teachers should be trained cognitively, affectively and socioculturally on overcoming anxiety-provoking factors.

3. Governmental precautions should be implemented urgently. Only under these circumstances, would pre-service EFL teachers be trained on teaching practicum effectively.

4. The pre-service EFL teachers should be informed on many sources of teaching aspects as teaching practicum is the last phase of being a teacher.

5. The practice teachers should have an in-service training on teaching practicum. If they do not have an in-service training related with teaching practicum courses, they should not be appointed as practice teachers for pre-service EFL teachers.

Among one of the most important limitations of this study was the number of participants as the total participants were only 25 pre-service EFL teachers at a state university. And the second limitation can be considered as it was only the results of a qualitative data obtained from interviews, reflections and essay papers.

\section{CONCLUSION}

The results of this study suggested that the pre-service EFL teachers were moderately anxious about teaching EFL and they were all aware of the ways on how to overcome anxiety-provoking factors. In this study, three main conclusions were reached. Firstly, the pre-service EFL teachers revealed how to overcome anxiety-provoking factors. Speaking specifically, as the causes that provoked FLTA have already been classified under cognitive, affective and socio-cultural factors, this study only focused on how to overcome these anxiety-provoking factors. Second, the study concluded that FLTA is different from foreign language learning anxiety. Namely, in terms of cognitive resolutions, the pre-service EFL teachers needed to be well-informed on the process of teaching practicum, curriculum, interactive boards and active language learning techniques. In terms of affective resolutions, the pre-service EFL teachers needed to be motivated as real teachers, to be trained on class management, to have a good interaction with practice teachers and supervisors as well as students. In terms of socio-cultural resolutions, pre-service EFL teachers preferred to be introduced as real teachers, to be trained by experienced practice teachers, to practice in class without surveillance of practice teachers, to be informed with constructive feedback, to be treated as persons who need guidance. Third, this study also included some other official resolutions in order to overcome anxiety-provoking factors among pre-service EFL teachers.

Acknowledgements. The author of this research paper would like to mention and thank Ballkesir University, Scientific Research Projects Department for their support as this paper is two of three segments of a project with the ID of 2017/175 entitled A Qualitative Research: On Foreign Language Teaching Anxiety among Pre-service Teachers of English as a Foreign Language (EFL). 


\section{REFERENCES}

Anandari, C. L. (2015). Indonesian EFL Students' Anxiety in Speech Production: Possible Causes and Remedy, TEFLIN Journal: A publication on the teaching and learning of English, 26(1), 1-16.

Aslrasouli, M., \& Vahid, M. S. P. (2014). An investigation of teaching anxiety among novice and experienced Iranian EFL teachers across gender. Procedia-Social and Behavioral Sciences, 98, 304-313.

Backman, N. (1976) Two measures of affective factors as they relate to progress in adult second language learning. Working Papers in Bilingualism, 10, 100-122.

Bailey, P., Daley, C. E. \& Onwuegbuzie, A. J. (1999), Foreign Language Anxiety and Learning Style. Foreign Language Annals, 32, 63-76.

Bosmans, D., \& Hurd, S. (2016). Phonological attainment and foreign language anxiety in distance language learning: a quantitative approach. Distance Education, 37(3), 287-301.

Croker, A. R. An introduction to qualitative research (2009) in Heigham, J., \& Croker, R. (Eds.). Qualitative research in applied linguistics: A practical introduction. London: Palgrave Macmillan.

Dewaele, J. M., Petrides, K. V., \& Furnham, A. (2008). Effects of trait emotional intelligence and sociobiographical variables on communicative anxiety and foreign language anxiety among adult multilinguals: $A$ review and empirical investigation. Language Learning, 58(4), 911-960.

Duxbury, J. G., \& Tsai, L. L. (2010). The effects of cooperative learning on foreign language anxiety: A comparative study of Taiwanese and American universities. International Journal of Instruction, 3(1), 3-18.

Dörnyei, Z. (2005). The psychology of language learner: Individual differences in second language acquisition. Mahvah, NJ: Lawrence Erlbaum.

Dörnyei, Z. (2007). Research methods in applied linguistics: Quantitative, qualitative, and mixed methodologies. Oxford: Oxford University Press.

GhorbanDordinejad, F., \& Nasab, A. H. F. (2013). Examination of the relationship between perfectionism and English achievement as mediated by foreign language classroom anxiety. Asia Pacific Education Review, 14(4), 603-614.

Güvendir, E. (2014). Using think-aloud protocols to identify factors that cause foreign language reading anxiety. Reading, 14(2), 109-118.

Horwitz, E. K., Horwitz, M. B., \& Cope, J. (1986). Foreign language classroom anxiety. The Modern language journal, 70(2), 125-132.

Horwitz, E. K. (1996). Even teachers get the blues: Recognizing and alleviating language teachers' feelings of foreign language anxiety. Foreign Language Annals, 29(3), 365-372.

Hurd, S., \& Xiao, J. (2010). Anxiety and affective control among distance language learners in China and the UK. RELC Journal, 41(2), 183-200.

Johnson, E. W., Johnson, R. T., \& Holubec, E. J. (1990). Circles of learning: Cooperation in the classroom. Edina, MN: Interaction Book.

Kayaoglu, M. N., \& Saglamel, H. (2013). Students' perceptions of language anxiety in speaking classes. Journal of History Culture and Art Research, 2(2), 142-160. 
Kim, S. Y. (2009). Questioning the stability of foreign language classroom anxiety and motivation across different classroom contexts. Foreign Language Annals, 42(1), 138-157.

Kondo, D. S., \& Ying-Ling, Y. (2004). Strategies for coping with language anxiety: The case of students of English in Japan. Elt Journal, 58(3), 258-265.

Kunt, N., \& Tüm, D. Ö. (2010). Non-native student teachers' feelings of foreign language anxiety. Procedia-Social and Behavioral Sciences, 2(2), 467-Llinás, M., \& Garau, M. J. (2009). Effects of language anxiety on three proficiency-level courses of Spanish as a foreign language. Foreign Language Annals, 42(1), 94-111.

Matsuda, S., \& Gobel, P. (2004). Anxiety and predictors of performance in the foreign language classroom. System, 32(1), 21-36.

Merç, A. (2010). Self-reported problems of pre-service EFL teachers throughout teaching practicum. Anadolu University, Journal of Social Sciences, 10(2), 199-226.

Merç, A. (2015). Foreign language teaching anxiety and self-efficacy beliefs of Turkish pre-service EFL teachers. The International Journal of Research in Teacher Education, 6(3), 40-58.

Nejad, S. G., \& Keshavarzi, A. (2015). The Effect of Cooperative Learning on Reading Comprehension and Reading Anxiety of Pre-University Students. Journal of Applied Linguistics and Language Research, 2(8), 169-180.

Oxford, R. L. (1997). Cooperative learning, collaborative learning, and interaction: Three communicative strands in the language classroom. The Modern Language Journal, 81, 443-456.

Pichette, F. (2009). Second language anxiety and distance language learning. Foreign Language Annals, 42(1), 77-93.

Rossman, G. B., \& Rallis, S. F. (2003). Learning in the field: An introduction to qualitative research. London: Sage.

Slavin, R. E. (1991). Synthesis of research on cooperative learning. Educational Leadership, 48, 71-82.

Suwantarathip, O., \& Wichadee, S. (2010). The impacts of cooperative learning on anxiety and proficiency in an EFL class. Journal of College Teaching and Learning, 7(11), 51.

Szyszka, M. (2011). Foreign language anxiety and self-perceived English pronunciation competence. Studies in Second Language Learning and Teaching, 2(1), 283-300.

Tanveer, M. (2007). Investigation of the factors that cause language anxiety for ESL/EFL learners in learning speaking skills and the influence it casts on communication in the target language (Master's thesis). University of Glasgow, England. Retrieved from http://www.asian-efl-journal.com/thesis_M_Tanveer.pdf

Trang, T. T. T., \& Moni, K. (2015). Management of foreign language anxiety: Insiders' awareness and experiences. Cogent Education, 2(1), 1-20.

Trang, T. T. T., Baldauf, R. B., \& Moni, K. (2013). Foreign language anxiety: Understanding its status and insiders' awareness and attitudes. Tesol Quarterly, 47(2), 216-243.

Tucker, R. E. (1976) Affective, cognitive, and social factors in second language acquisition. Canadian Modern Language Review, 32(3), 214-226.

Tum, D. O. (2012). Feelings of language anxiety amongst non-native student teachers. Procedia: Social and Behavioral Sciences, 47, 2055-2059. 
Tum, D. O. (2015). Foreign language anxiety's forgotten study: The case of the anxious preservice teacher. Tesol Quarterly, 49(4), 627-658.

Tüfekçi-Can, D. (2018). Pre-service teachers' foreign language teaching anxiety during teaching practicum. International Online Journal of Education and Teaching (IOJET), 5(3). 579-595.

Wu, K. H. (2010). The relationship between language learners' anxiety and learning strategy in the CLT classrooms. International Education Studies, 3(1), 174.

Young, D. J. (1986) The relationship between anxiety and foreign language oral proficiency ratings. Foreign Language Annals, 19, 439-445.

Zoghi, M., \& Alivandivafa, M. (2014). EFL Reading Anxiety Inventory (EFLRAI) Factorial Validity and Reliability. Journal of Psychoeducational Assessment, 32(4), 318-329. 